Date of Publication: 27 May 2014

\section{Cunninghamia}

A journal of plant ecology for eastern Australia

\title{
Vegetation of Little Bora Nature Conservation Trust Agreement, North Western Slopes, New South Wales
}

\author{
John T. Hunter \\ School of Behavioural Cognitive and Social Sciences, University of New England, Armidale, NSW 2350. Email: jhunter8@ bigpond.com
}

\begin{abstract}
The vegetation of the Little Bora Nature Conservation Trust Agreement property (560 ha in area), $8 \mathrm{~km}$ south east of Bingara (lat $29^{\circ} 55^{\prime} \mathrm{S}$ long $150^{\circ} 37^{\prime}$ ) in the Gwydir Shire and within the Nandewar Bioregion is described. Eight vegetation communities are defined based on flexible UPGMA analysis of cover-abundance scores of all vascular plant taxa. These communities are mapped based on ground truthing, ADS40 imagery interpretation, topography and substrate. Communities described are: 1) Melaleuca bracteata - Eucalyptus melanophloia - Eucalyptus camaldulensis Woodland, 2) Callitris glaucophylla - Eucalyptus melanophloia - Eucalyptus albens Woodland, 3) Callitris glaucophylla - Eucalyptus melanophloia - Brachychiton populneus Woodland, 4) Eucalyptus albens Woodland, 5) Eucalyptus caleyi - Eucalyptus albens - Callitris glaucophylla Woodland, 6) Callitris glaucophylla - Eucalyptus melanophloia - Eucalyptus albens Woodland, 7) Austrostipa verticillata - Austrostipa scabra Derived Grassland, 8) Eucalyptus melliodora - Eucalyptus dealbata Woodland. A total of 232 vascular plant taxa were found of which 14\% were considered exotic in origin. 66 ha of listed threatened communities were mapped along with populations of a currently listed Extinct plant (TSC Act) Dodonaea stenophylla.
\end{abstract}

Key words: vegetation, mapping, condition, conservation, Little Bora, floristics, woodland, north western slopes, Bingara

Cunninghamia (2014) 14: 1-16

doi 10.7751/cunninghamia.2014.14.001

\section{Introduction}

Little Bora Nature Conservation Trust property is located within the Nandewar Bioregion on the North Western Slopes of New South Wales. The property lies approximately 8 $\mathrm{km}$ south east of Bingara (lat $29^{\circ} 55^{\prime} \mathrm{S}$ long $150^{\circ} 37^{\prime}$ ) in Gwydir Shire local government area. The property contains 560 ha of private lands and was purchased by the current owner from the Nature Conservation Trust in August 2007, the first property to be sold on to a private landholder by this revolving fund. Its history has been dominated by logging with a local mill being once established on the property and in later years by grazing of cattle (G. Chorley, pers. comm. 2012).
The Bingara Community Conservation Reserves which include Derra Derra, Mehi, Molroy, Munro, Murchison, Noonga, Salmon and Sepoy occur within the vicinity of Little Bora (Fig. 1). These reserves were primarily State Forests and Crown Lands although some sections (Noonga) were privately owned. Another Nature Conservation Trust Agreement property, Euroka occurs nearby (Fig. 1). These reserves, including Euroka, have recently had their flora and vegetation surveyed and vegetation mapping produced and share many similar landscapes and vegetation types (Benson et al. 1996; Hunter 2009abl; Hunter 2010ab; Hunter 2011b; Hunter 2012abcd; Hunter 2013b). 
The study area is a rugged landscape primarily of metasedimentary geology. Altitudes range from 310-660 m above sea level. The topology of the landscape is of extensive elevated ridgelines than run in a south eastern direction. The northern boundary forms part of lowland areas associated with the Gwydir River. The property also contains two creek lines that flow into the Gwydir River, the larger being Little Bora Creek.

This paper provides part of the results of a flora survey conducted to provide baseline data for the future management of the private conservation area, to construct a map of vegetation communities and their condition and to provide information on the distribution of rare taxa. A comparison of different forms of community circumscription and mapping is also made, particularly between methods based on floristic analysis and that required by Threatened Ecological Communities (TECs) listed under the Commonwealth Environmental Protection and Biodiversity Act (EPBC) and the New South Wales Threatened Species Conservation Act (TSC). This information will be used to assist the development of appropriate management strategies (Hunter 2012d).

\section{Methods}

Forty eight, $20 \times 20 \mathrm{~m}$ quadrats were surveyed for vascular plants scored using the Braun-Blanquet six point cover abundance scale (Westhoff \& Maarel 1978) in the Little Bora Nature Conservation Trust Agreement property. Quadrats were placed using a stratified random method using: altitude, aspect and physiography (crest \& upper slope, lower slope $\&$ flats, open depressions). At each full floristic survey site structural information was also recorded which included the length and density of logs on ground, tree diameter sizes, tree height and the number of hollows. This information was used along with other notes taken to assist in the mapping of condition classes. A further 17 sites which only recorded the dominant three species in each of the major structural layers were also placed across the property to assist in recognition of vegetation types when conducting ADS40 image interpretation. The survey was conducted over a period of two days during late September of 2012.

Analyses and data exploration were performed using options available in the PATN 3.2 Analysis Package (Belbin 1995a, b). For final presentation of results all species and their relative abundance scores were used and the analysis performed using

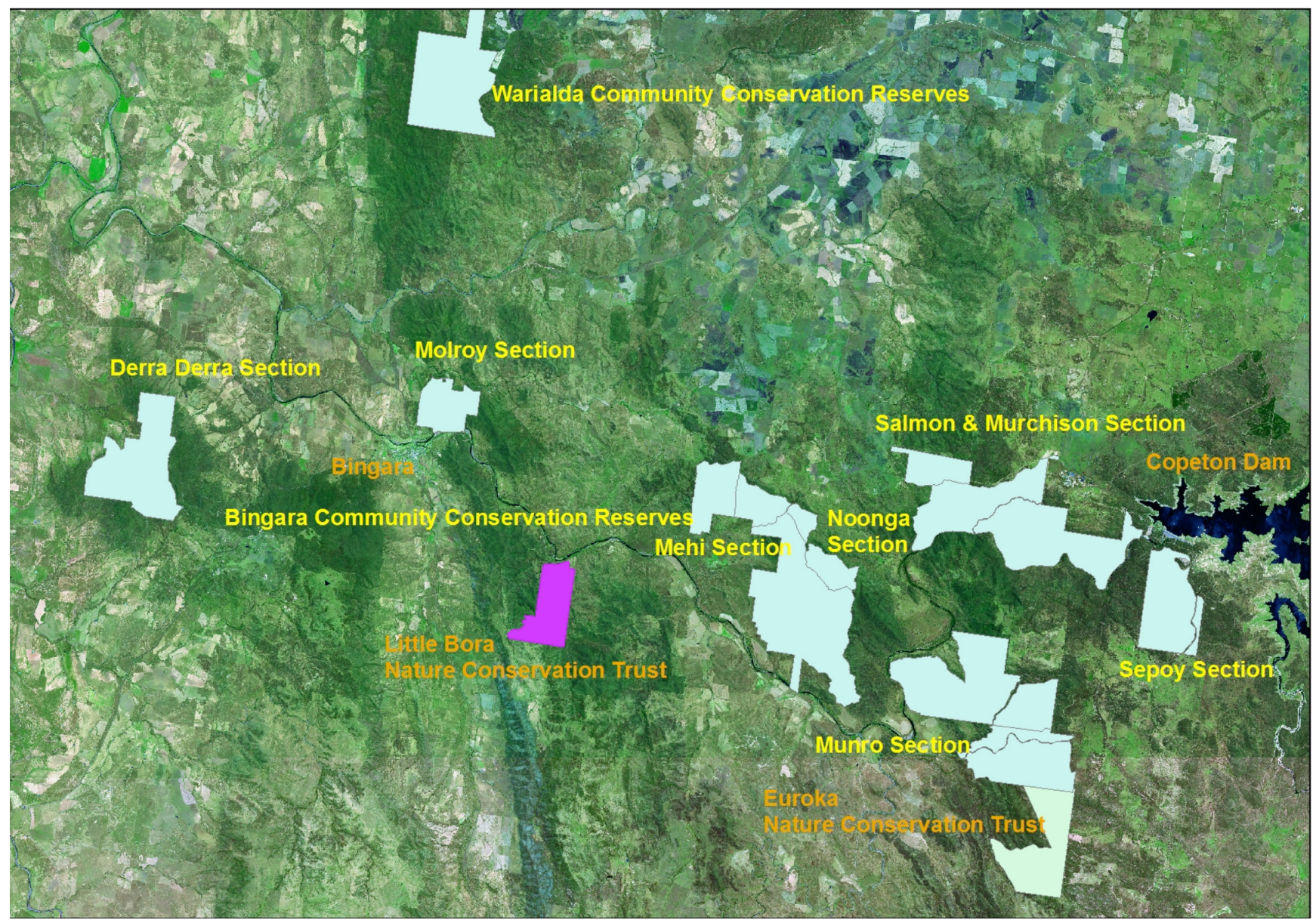

Fig. 1. Location of Little Bora Nature Conservation Agreement and other reserves in the Bingara area. 
Kulczynski association measure which is recommended for ecological applications (Belbin 1995ab) along with flexible Unweighted Pair Group arithMetic Averaging (UPGMA) and the default PATN settings. Each site (full floristic and RDP) were assigned a community mapping code retrospectively based on the results of the statistical analysis of the full floristic survey sites. The sites and their assigned community identity were re-projected onto satellite (ADS40) imagery using GIS software. These sites, the notes taken on traverses, structural characteristics seen on satellite images along with projected topographical and rock type information was used to delineate vegetation polygons. This methodology follows the guidelines for vegetation mapping provided within the Native Vegetation Interim Type Standard (Sivertsen 2009).

Threatened Ecological Communities listed under the NSW Threatened Species Conservation Act or Commonwealth Environmental Protection \& Biodiversity Conservation Act are not always direct correlations to floristic units and as such each mapping unit was scored in a subsidiary field for its potential inclusion within any listed TEC. Quality was scored in three categories which were derived based on a summation of information collected at each site including recognisable disturbances, weed infestations and features known to be of importance to community quality and fauna habitat. Sites in moderate condition often lacked some important fauna habitat elements. Commonly these were stands of younger-aged trees representative of the original overstorey, with some isolated mature trees and a predominantly native understorey. Low condition sites often had little of the original overstorey cover, supported few if any features important for fauna habitat, and had high weed infestations. While these subtypes of condition are generally due to time constraints and not fully quantifiable, they form an important assessment to assist in management planning. With more time and resources this type of assessment can be improved whereby appropriate attributes are specifically measured and analyses performed to more critically and objectively separate condition classes.

\section{Results and Discussion}

In the Little Bora Nature Conservation Trust Agreement property, eight vegetation communities were recognized at the dissimilarity measure of 0.74 ; a summary of community relationships is given in the dendrogram (Figure 2). Delineation of community boundaries and their condition are presented in Figures 3 and 4. Over the two day survey period a total of 232 vascular plant taxa were found from 70 families and 158 genera with $14 \%$ being exotic in origin. Approximately $65 \%$ of the property was considered to be in good condition with only $7 \%$ being in poor condition (Table 1). As is typical communities in good condition were restricted to the hills and ridges and more inaccessible country while the more fertile country on the lower slopes and valleys were more likely to be in moderate to poor condition.

Table 1: Selected attributes of the eight defined communities in the Little Bora Nature Conservation Trust Agreement property.

\section{Community}

C1: Melaleuca bracteata - Eucalyptus melanophloia - Eucalyptus camaldulensis

C2: Callitris glaucophylla - Eucalyptus melanophloia - Eucalyptus albens

C3: Callitris glaucophylla - Eucalyptus melanophloia - Brachychiton populneus

C4: Eucalyptus albens

C5: Eucalyptus caleyi - Eucalyptus albens Callitris glaucophylla

C6: Callitris glaucophylla - Eucalyptus melanophloia - Eucalyptus albens

C7: Austrostipa verticillata-Austrostipa scabra

C8: Eucalyptus melliodora-Eucalyptus dealbata

$\begin{array}{ccc}\begin{array}{c}\text { Number } \\ \text { of Sites }\end{array} & \begin{array}{c}\text { Richness } \\ \text { per } \mathbf{4 0 0} \mathbf{~ m}^{2} \\ \text { (average) }\end{array} & \begin{array}{c}\text { Number } \\ \text { of Species }\end{array} \\ 6 & 29-39(34) & 85 \\ 29 & 27-40(31) & 147 \\ 6 & 24-34(30) & 76 \\ 1 & 30 & 30 \\ 5 & 20-27(23) & 59 \\ 13 & 18-55(30) & 116 \\ 3 & 18-32(18) & 46 \\ 2 & 15-22(19) & 29\end{array}$

Good

Moderate Poor

Introduced Species

\begin{tabular}{|c|c|c|c|}
\hline 14 & 13.1 ha $(2 \%)$ & & \\
\hline 12 & 296 ha $(53 \%)$ & 87.8 ha $(16 \%)$ & 33.6 ha $(6 \%)$ \\
\hline 3 & 20.3 ha $(4 \%)$ & 20.5 ha $(4 \%)$ & 5.2 ha $(1 \%)$ \\
\hline 3 & & 0.1 ha $(<0.0 \%)$ & \\
\hline 4 & 33 ha $(6 \%)$ & & \\
\hline 21 & & 1 ha $(<1 \%)$ & 38 ha $(7 \%)$ \\
\hline 11 & & & 4.7 ha $(1 \%)$ \\
\hline 11 & & & 5.2 ha $(1 \%)$ \\
\hline & $\begin{array}{c}362.4 \text { ha } \\
(65 \%)\end{array}$ & 108.4 ha $(19 \%)$ & 38.8 ha $(7 \%)$ \\
\hline
\end{tabular}

Table 2: Condition and area (hectares) of Threatened Ecological Communities in the Little Bora Nature Conservation Trust Agreement property

TEC Type

Aquatic Ecological Community in the Natural Drainage System of the Lowland Catchment of the Darling River (FIsheries Act)

White Box - Yellow Box - Blakely's Red Gum Grassy Woodland and Derived Native Grassland (EPBC \& TSC Act)

Semi-evergreen Vine Thickets of the Brigalow Belt (North \& South) and Nandewar Bioregions (EPBC \& TSC Act)
Good Moderate Poor

13

0.5

5

$21 \quad 21$ 


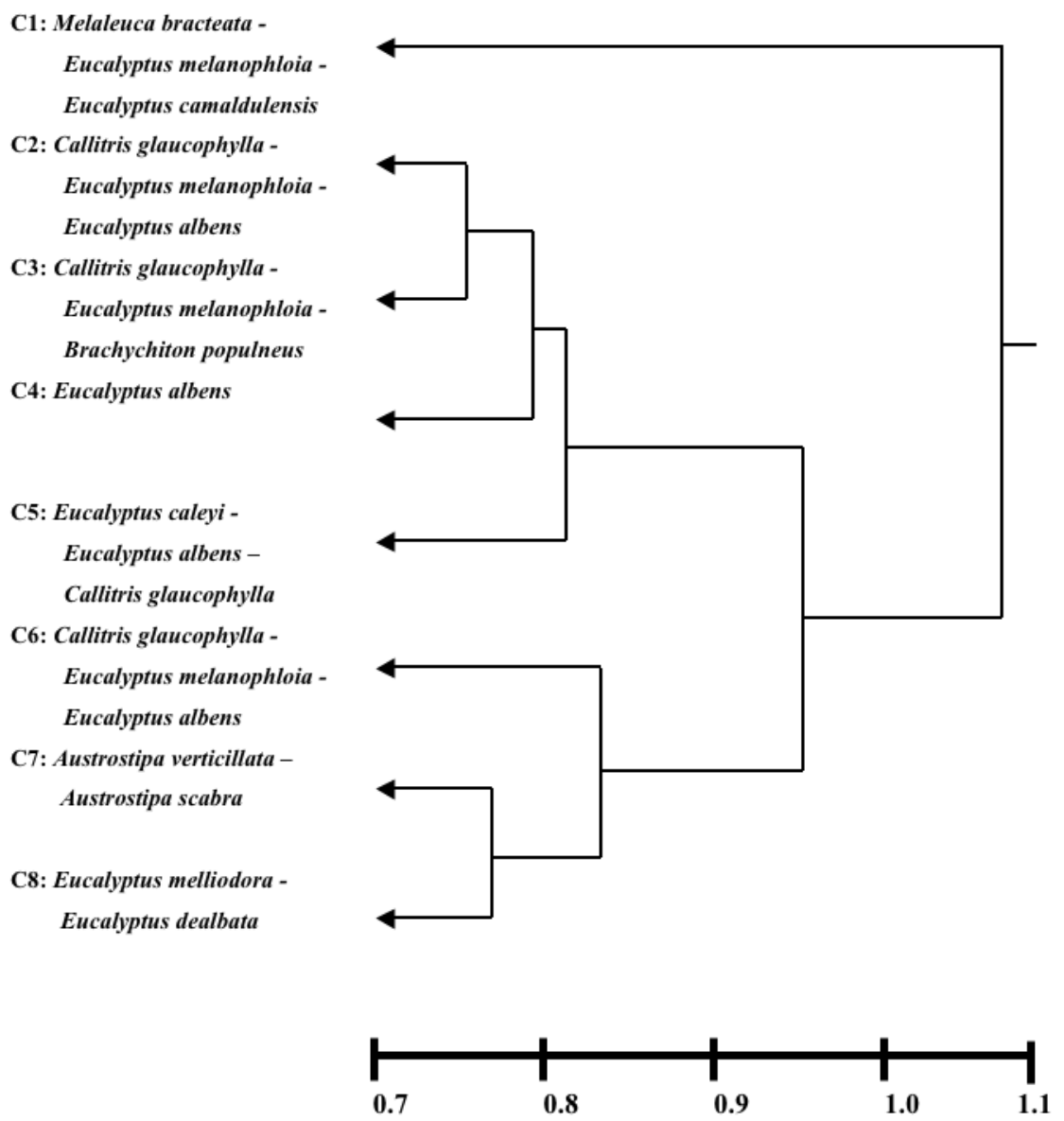

Fig. 2. Summary dendrogram of the full floristic dataset of sites using Kulczynski association and flexible UPGMA fusion strategy recorded in the Little Bora Nature Conservation Trust Agreement property. Delineation of communities occurs at a dissociation of 0.75.

\section{Vegetation communities}

Community 1: Melaleuca bracteata (Black Tea-tree) - Eucalyptus melanophloia (Silver-leaved Ironbark) Eucalyptus camaldulensis (River Red Gum) Riparian Layered Woodland

Structure: highly variable but predominantly a layered shrubby woodland, woodland, closed scrub or closed shrubland or dry rainforest.

Trees: Eucalyptus melanophloia, Eucalyptus camaldulensis, Callitris glaucophylla, Angophora floribunda, Eucalyptus dealbata, Eucalyptus melliodora.

Tall shrubs: Melaleuca bracteata, Alectryon subdentatus, Geijera parviflora, Alstonia constricta, Acacia leiocalyx

Shrubs: Notelaea microcarpa, Phyllanthus subcrenulatus, Nyssanthes diffusa, Cryptandra amara var. floribunda, Bursaria spinosa, Abutilon oxycarpum, Solanum parvifolium, Xanthorrhoea johnsonii, Pimelea neo-anglica, Olearia elliptica, Macrozamia diplomera, Isotropis foliosa, Hibbertia obtusifolia, Dodonaea viscosa, Carissa ovata.

Climbers \& trailers: Eustrephus latifolius, Pandorea pandorana, Glycine tabacina, Glycine microphylla, Desmodium varians.

Ground cover: Microlaena stipoides, Adiantum atroviride, Scleranthus biflorus, Daucus glochidiatus, Poa sieberiana, Geranium solanderi, Wahlenbergia communis, Urtica incisa, Galium migrans, Dichondra repens, Carex incomitata, Austrostipa verticillata, Swainsona galegifolia, Rumex brownii, Ranunculus sessiliflorus, Stellaria flaccida, Rorippa eustylis, Pratia purpurascens, Pellaea calidirupium, Oplismenus aemulus, Lomandra multiflora, Haloragis heterophylla, Cynodon dactylon, Crinum flaccidum, Rorippa laciniata, Pellaea calidirupium, Oxalis perennans, Lepidosperma laterale, Juncus aridicola, Gonocarpus micranthus, Galium gaudichaudii, Euchiton sphaericus, Dichondra sp. A, Desmodium brachypodum, Cyperus gracilis, Cheilanthes sieberi, Calochlaena dubia, Asplenium flavellifolium, Ajuga australis.

Introduced taxa: Trifolium repens, Sonchus oleraceus, Verbena bonariensis, Stellaria media, Opuntia stricta, Cyperus eragrostis, Conyza bonariensis, Centaurium tenuiflorum, Stachys arvensis, Paronychia brasiliana, Hypochaeris radicata, Hypochaeris glabra, Cirsium vulgare, Ciclospermum leptophyllum.

Notes \& conservation status: all of this community falls within the Endangered Aquatic community in the Natural Drainage System of the Lowland Catchment of the Darling River which includes the Gwydir River from Copeton Dam downstream and incorporates the main channels and tributaries such as all natural creeks, streams and associated floodplains. This determination also encompasses deep channels, deep pool areas, suspended load depositional 'benches', higher floodplain 'benches', braided channels, gravel beds and riffle zones. Implicit in this determination is the protection of associated vegetation to enable the persistence of the aquatic community that depends upon it. This community often occurs in protected gullies with an increase in moisture availability, it often has an understorey of mesic taxa including Alectryon subdentatus and Notelaea microcarpa and in some instances these can form dense Semi-evergreen Vine Thicket stands on protected slopes immediately adjacent to the stream edge. In the lower reaches Eucalyptus camaldulensis (River Red Gum) occurs. 


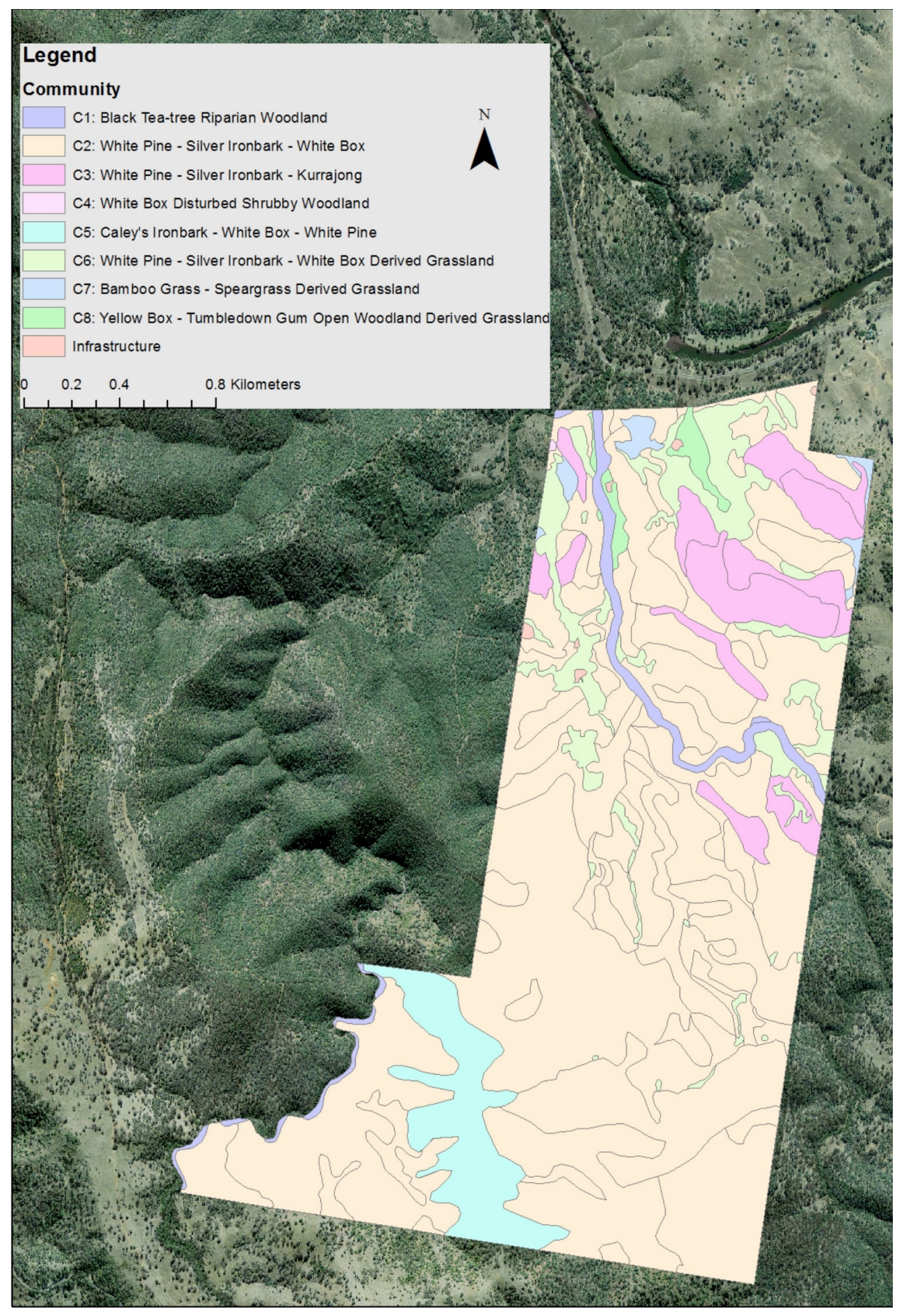

Fig. 3. Map of vegetation communities in the Little Bora Nature Conservation Trust Agreement. 


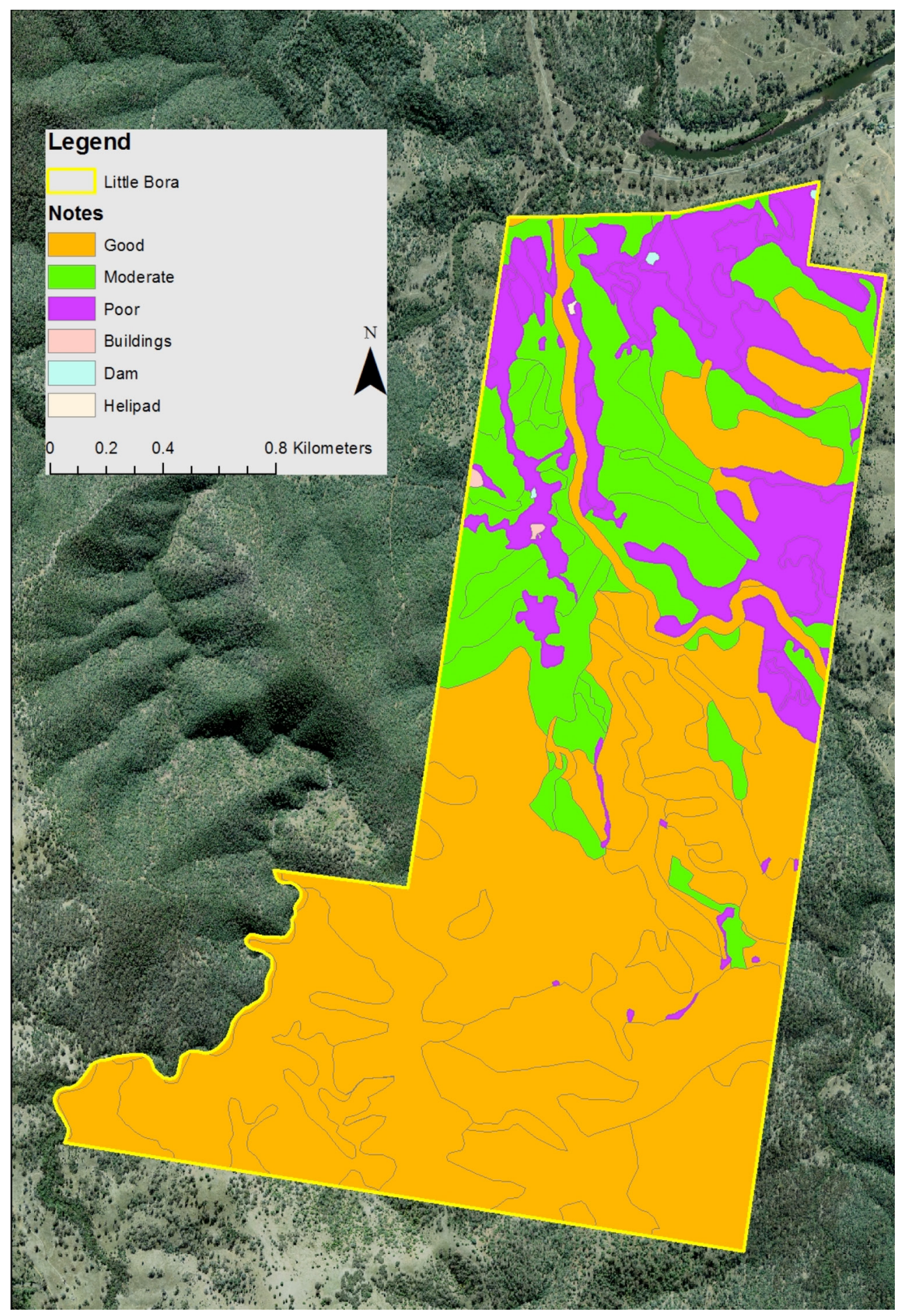

Fig. 4. Map of vegetation condition in the Little Bora Nature Conservation Trust Agreement. 


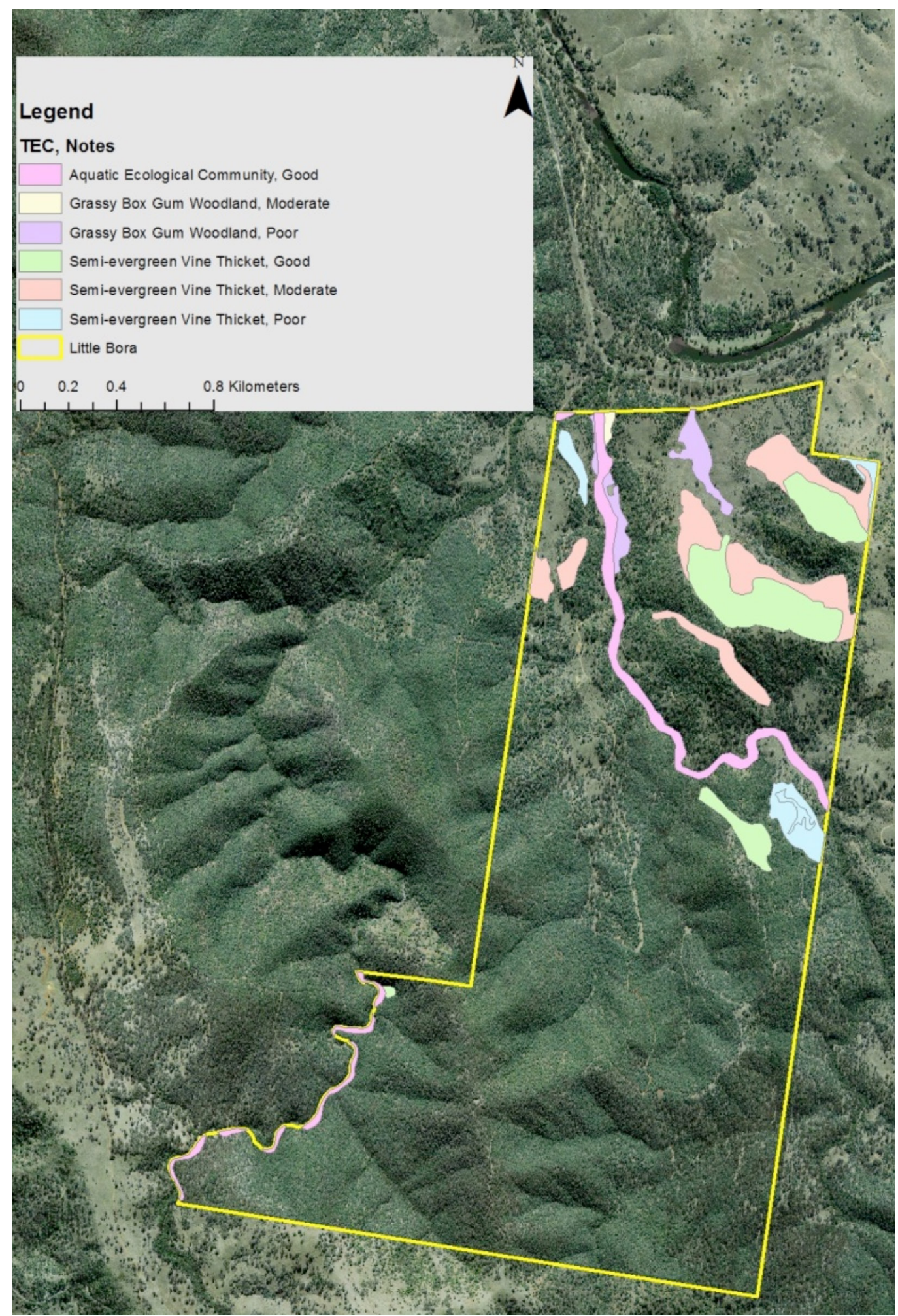

Fig. 5. Map of Threatened Ecological Communities (TECs) and their condition in the Little Bora Nature Conservation Trust Agreement. 


\section{Community 2: Callitris glaucophylla (White Cypress Pine) - Eucalyptus melanophloia (Silver-leaved Ironbark) - Eucalyptus albens (White Box) Shrubby Woodland}

Structure: generally a shrubby woodland but at times a layered woodland, open woodland or grassy woodland.

Trees: Callitris glaucophylla, Eucalyptus melanophloia, Eucalyptus albens, Eucalyptus crebra, Eucalyptus sideroxylon, Brachychiton populneus, Eucalyptus dealbata, Eucalyptus melliodora, Angophora floribunda.

Tall shrubs: Acacia leiocalyx, Alphitonia excelsa, Geijera parviflora.

Shrubs: Notelaea microcarpa, Carissa ovata, Olearia elliptica, Hibbertia obtusifolia, Pimelea neo-anglica, Solanum parvifolium, Hibiscus sturtii, Cassinia quinquefaria, Capparis mitchellii, Breynia cernua, Acacia deanei, Hibbertia riparia, Dodonaea sinuolata, Bursaria spinosa.

Climbers \& trailers: Desmodium varians, Pandorea pandorana, Glycine tabacina, Clematis microphylla, Parsonsia eucalyptophylla, Marsdenia viridiflora, Jasminum lineare.

Ground cover: Aristida personata, Cymbopogon refractus, Dichondra sp. A, Desmodium brachypodum, Austrostipa scabra, Wahlenbergia communis, Brunoniella australis, Cheilanthes sieberi, Swainsona galegifolia, Microlaena stipoides, Eragrostis parviflora, Calotis lappulacea, Scleria mackaviensis, Lomandra multiflora, Vittadinia dissecta, Vittadinia cuneata, Galium migrans, Plantago varia, Panicum simile, Geranium solanderi, Aristida calycina, Chloris truncata, Cheilanthes distans, Sigesbeckia australiensis, Rostellularia adscendens, Hypericum gramineum, Cyperus gracilis, Bothriochloa decipiens.

Introduced taxa: Conyza bonariensis, Opuntia stricta, Opuntia aurantiaca, Bidens pilosa, Cirsium vulgare, Anagallis arvensis, Verbascum virgatum, Sonchus oleraceus, Plantago lanceolata, Hypochaeris radicata, Conyza sumatrensis, Abutilon theophrasti.

Notes \& conservation status: the understorey of this assemblage is reasonably stable despite some noticeable overstorey changes. The species that occur within the overstorey do not seem to form distinctive floristic groups based on analysis but are visually distinct in the field and at times can be recognised on the imagery used for mapping due to differences in crown reflectance. Thus four crown sub-community units maybe discernible and could include monodominant stands of Eucalyptus melanophloia, stands of Eucalyptus crebra, stands of Eucalyptus albens/moluccana and stands of Eucalyptus sideroxylon. However it must be emphasised that these do not represent true floristic sub-associations but only discernible overstorey units. Benson et al. (1996) describe this as Eucalyptus melanophloia, Eucalyptus albens and Callitris glaucophylla and its type probably restricted to the Peel and Gwydir Valleys. It is very common within the local region and is one of the dominant community types within the Bingara Community Conservation Areas (Derra Derra and Molroy) and the Gwydir River National Park (Mehi, Noonga, Murchison, Salmon, Munro), Warialda Community Conservation Reserves and within Euroka Nature Conservation Trust property (Hunter 2009a; 2010ab; 2011a; 2012abc). Within the Terry Hie Hie region to the west of the study area this community is also found within Bullala National Park and Irrigappa, Campbell, Montrose, Courallie, the Mission, Berrygill and Terry Hie Hie Aboriginal Areas (Hunter 2009defghi). Somewhat similar communities are known to exist at Arakoola Nature Reserve, Kwiambal National Park, Bullala National Park, Gunyerwarildi National Park and Planchonella Nature Reserve (Hunter et al. 1999; Hunter 2003; 2006; 2009cj). Beadle (1981) describes Eucalyptus albens as being particularly common on soils with a high base status particularly in calcium and generally of high fertility. Eucalyptus sideroxylon was also recorded within this assemblage. Eucalyptus sideroxylon is known from the most westerly forests within eastern Australia in a rainfall zone of 350 to $650 \mathrm{~mm}$ and usually occurs on soils of low fertility often sandy soils that may be surrounded by more fertile texture-contrast soils (Beadle 1980). Eucalyptus sideroxylon is a dominant at lower to mid altitudes within the property within the south western corner. Some very significant remnant mature stands of Eucalyptus sideroxylon occur. Callitris glaucophylla at times forms a dense and often monodominant canopy within this community, however recent research that includes data gathered during this current investigation shows that such dense stands only increase species density (species per site) (Hunter $2011 \mathrm{a} ; 2013 \mathrm{a})$ and thus do not reduce the number of species found within a location no matter how dense the stands become.

Community 3: Callitris glaucophylla (White Cypress Pine) - Eucalyptus melanophloia (Silver-leaved Ironbark) - Brachychiton populneus (Kurrajong) Woodland and Semi-evergreen Vine Thicket

Structure: highly variable but often a Semi-evergreen Vine Thicket, low open shrubby woodland and shrubby woodland.

Trees: Callitris glaucophylla, Eucalyptus melanophloia, Brachychiton populneus, Eucalyptus albens.

Tall shrubs: Geijera parviflora, Alphitonia excelsa, Alstonia constricta, Acacia leiocalyx.

Shrubs: Notelaea microcarpa, Carissa ovata, Dodonaea viscosa, Bursaria spinosa, Pimelea neo-anglica, Santalum acuminatum, Psydrax odoratum, Breynia cernua, Acacia decora, Cassinia quinquefaria, Beyeria viscosa, Abutilon oxycarpum.

Climbers \& trailers: Clematis microphylla, Jasminum lineare, Marsdenia viridiflora, Desmodium varians, Parsonsia eucalyptophylla, Glycine microphylla.

Ground cover: Malvastrum coromandelianum, Bothriochloa decipiens, Aristida personata, Wahlenbergia communis, Austrostipa scabra, Swainsona galegifolia, Cymbopogon refractus, Calotis lappulacea, Paspalidium constrictum, Eragrostis parviflora, Dichondra sp. A, Desmodium brachypodum, Austrostipa verticillata, Vittadinia dissecta, Scleria mackaviensis, Lomandra multiflora, Glossocardia bidens, Cheilanthes sieberi, Sigesbeckia australiensis, Oxalis perennans, Geranium solanderi, Eragrostis leptostachya, Cyperus gracilis, Brunoniella australis, Ajuga australis.

Introduced taxa: Opuntia aurantiaca, Conyza bonariensis, Abutilon theophrasti.

Notes \& conservation status: this community in most instances would fall within the TSC Act determination of Semi-evergreen Vine Thicket whose characteristic species include a canopy of Cassine australis, Geijera parviflora, Notelaea microcarpa with an emergent overstorey of Eucalyptus albens, Eucalyptus melanophloia and Callitris glaucophylla with associated species such as Alectryon subdentatus, Alstonia constricta, Aristida ramosa, Beyeria viscosa, Boerhavia dominii, Psydrax oleifolium, Carissa ovata, Cheilanthes sieberi, Dichondra repens, Dodonaea viscosa, Indigofera brevidens, Pandorea pandorana, Parsonsia eucalyptophylla, Phyllanthus subcrenulatus, Pimelea neoanglica, Spartothamnella juncea and Thellungia advena. Out of a these 23 characteristic species all but one were found within this community. The TSC Act determination is included within the Federal EPBC Act determination of Semi-evergreen Vine Thickets. Curran et al. (2008) described this community as Floristic Group 3: Elaeodendron australe, Geijera parviflora and Notelaea microcarpa and Floristic Group 5: Notelaea microcarpa, Geijera parviflora and Ehretia membranifolia. This grouping occurs predominantly within the North Western Slopes of New South Wales. Semi-evergreen vine thicket (SEVT) is a type of rainforest that occurs on the North West Slopes of New South Wales, extending north from the Liverpool Range through southern and central Queensland to areas inland of Townsville. Outliers also occur in the upper Hunter Valley of NSW, near Scone. Vine thicket has the structural (when best developed a dense, often closed canopy) and floristic (plant species composition) characteristics of rainforest, but because of its low height (generally 4-9 m) it cannot be considered to be forest (Curran, pers. comm.). Floyd (1990) places these communities within his Sub-alliance No. 32 Notelaea microcarpa - Ehretia membranifolia Geijera parviflora for his rainforest classification of New South Wales 
and includes vegetation as far south as the Hunter valley and north to Toowoomba. Floyd (1990) suggests that for optimal development of this community type rainfall is around $575-650 \mathrm{~mm}$.

\section{Community 4: Eucalyptus albens (White Box) Disturbed Open Shrubby Woodland}

Structure: a low open layered shrubby woodland.

Trees: Eucalyptus albens.

Shrubs: Cryptandra amara var. floribunda, Notelaea microcarpa, Acacia decora, Hibbertia obtusifolia, Cassinia quinquefaria, Carissa ovata, Acacia leiocalyx.

Climbers \& trailers: Desmodium varians, Clematis microphylla.

Ground cover: Cymbopogon refractus, Wahlenbergia communis, Tripogon loliiformis, Panicum simile, Oxalis perennans, Dichondra repens, Calotis lappulacea, Aristida personata, Poranthera microphylla, Oxalis chnoodes, Malvastrum coromandelianum, Lomandra multiflora, Glossocardia bidens, Geranium solanderi, Chrysocephalum semipapposum, Cheilanthes sieberi, Arthropodium milleflorum.

Introduced taxa: Opuntia aurantiaca, Bidens pilosa, Anagallis arvensis.

Notes \& conservation status: this is an unusual occurrence of disturbed Eucalyptus albens shrubby woodland and probably occurs within a transitional area between Community 3 and Community 1 . Some locations just above the creek line within the far south west of the property included areas within Community 2 had an understorey with dense stands of Cryptandra amara on shallow soils. These natural areas were only small in extent and very sporadic in occurrence. The location of this community was within reasonable proximity to creek and on shallow soils. It is likely that it is both a disturbed and intermediate assemblage with an unusual combination of floristics.

Community 5: Eucalyptus caleyi subsp. caleyi (Caley's Ironbark) - Eucalyptus albens (White Box) - Callitris glaucophylla (White Pine) Shrubby Woodland

Structure: a shrubby woodland.

Most common natives: listed in order of decreasing summed cover scores (fidelity x cover).

Trees: Eucalyptus caleyi, Eucalyptus albens, Callitris glaucophylla, Eucalyptus dealbata.

Tall shrubs: Alphitonia excelsa, Geijera parviflora, Acacia cheelii, Acacia neriifolia.

Shrubs: Olearia elliptica, Notelaea microcarpa, Pimelea neo-anglica, Solanum parvifolium, Spartothamnella juncea, Acacia deanei, Carissa ovata, Hibbertia obtusifolia, Bursaria spinosa, Breynia cernua.

Climbers \& trailers: Glycine microphylla, Parsonsia eucalyptophylla, Glycine clandestina, Eustrephus latifolius, Desmodium varians.

Ground cover: Cymbopogon refractus, Austrostipa scabra, Dichondra sp. A, Desmodium brachypodum, Swainsona galegifolia, Wahlenbergia communis, Notodanthonia longifolia, Lomandra multiflora, Aristida personata, Cyperus gracilis, Cheilanthes sieberi, Brunoniella australis, Aristida jerichoensis, Vittadinia cuneata, Lepidosperma laterale, Gonocarpus elatus, Einadia nutans, Carex inversa, Aristida calycina, Sida corrugata, Senecio prenanthoides, Paspalidium constrictum, Galium migrans, Eragrostis leptostachya, Einadia hastata, Dichondra repens, Dichelachne micrantha, Cheilanthes distans, Austrostipa verticillata, Arthropodium milleflorum.

Introduced taxa: Opuntia aurantiaca, Opuntia stricta, Abutilon theophrasti, Bidens pilosa.

Notes \& conservation status: Eucalyptus caleyi communities are more typical of the higher, and therefore correspondingly often eastern parts of the Nandewars such as around Ironbark Nature Reserve (Hunter \& Hunter 2003) also the western parts of the Northern Tablelands up to
Sundown National Park in Queensland. The assemblage as described here appears to be introgressional and contains a number of species more common with communities of lower altitudes. The community is therefore probably somewhat intermediate between those found in higher altitude areas in the eastern Nandewars such as Horton Falls National Park (Hunter 2009k) and those more typical of this locality (Community 2) such entities are also found within Warrabah National Park (Hunter 2008) and within the nearby Molroy section of the Bingara Community Conservation Reserves (Hunter 20091).

Community 6: Callitris glaucophylla (White Cypress Pine) - Eucalyptus melanophloia (Silver-leaved Ironbark) - Eucalyptus albens (White Box) Grassy Woodland \& Derived Grassland

Structure: highly variable due to past clearing practices and subsequent recovery. Generally a grassland, shrubland or layered open woodland.

Trees: Callitris glaucophylla, Eucalyptus melanophloia, Eucalyptus albens, Brachychiton populneus, Angophora floribunda, Eucalyptus moluccana, Eucalyptus dealbata.

Tall shrubs: Geijera parviflora, Acacia leiocalyx, Acacia implexa

Shrubs: Notelaea microcarpa, Carissa ovata, Maireana microphylla, Pimelea neo-anglica, Dodonaea viscosa.

Climbers \& trailers: Desmodium varians, Parsonsia eucalyptophylla, Jasminum lineare, Glycine tabacina, Glycine microphylla, Clematis microphylla.

Ground cover: Cymbopogon refractus, Bothriochloa decipiens, Austrostipa scabra, Aristida personata, Geranium solanderi, Poa sieberiana, Daucus glochidiatus, Oxalis perennans, Malvastrum coromandelianum, Dichondra sp. A, Bothriochloa macra, Vittadinia dissecta, Eragrostis leptostachya, Rumex brownii, Cymbonotus lawsonianus, Cheilanthes sieberi, Cyperus gracilis, Carex inversa, Calotis lappulacea, Wahlenbergia communis, Lomandra filiformis, Vittadinia muelleri, Microlaena stipoides, Hydrocotyle laxiflora, Galium migrans, Desmodium brachypodum, Chrysocephalum semipapposum, Wurmbea dioica, Veronica calycina, Swainsona galegifolia, Sida corrugata, Scleranthus biflorus, Plantago varia, Parietaria debilis, Panicum simile, Lomandra multiflora, Lomandra longifolia, Juncus aridicola, Haloragis exalata, Galium gaudichaudii, Enneapogon nigricans, Einadia nutans, Dichanthium sericeum, Chrysocephalum apiculatum, Chloris truncata, Carex incomitata, Brunoniella australis, Austrostipa verticillata, Adiantum atroviride.

Introduced taxa: Conyza bonariensis, Bidens pilosa, Verbena bonariensis, Opuntia aurantiaca, Anagallis arvensis, Hyparrhenia hirta, Cirsium vulgare, Hypochaeris glabra, Arctotheca calendula, Verbascum thapsus, Sonchus oleraceus, Medicago polymorpha, Verbascum virgatum, Trifolium repens, Trifolium dubium, Taraxacum officinale, Stachys arvensis, Hypochaeris radicata, Gomphocarpus fruticosus, Fumaria capreolata, Centaurea melitensis.

Notes \& conservation status: this community probably is a disturbed and degraded version of Community 2 or a similar assemblage but found on lower topographic sites. In some locations it probably did contain Semi-evergreen Vine Thicket that in time may recover. Most likely it originally contained a shrub layer greater than $30 \%$ within most situations and thus unlikely to have been Grassy Box Gum Woodland. Though considered to be largely in poor condition due to the removal of overstorey and shrubby vegetation the grass and herb components of this community at the time of survey were largely native in composition. Some locations had infestations of Hyparrhenia hirta (Coolatai Grass) and some areas may have a seasonal flush of exotic herbaceous species later in the season. 


\section{Community 7: Austrostipa verticillata (Slender Bamboo Grass) - Austrostipa scabra (Rough Speargrass) Derived Grassland}

Structure: variable depending on past clearing activities and subsequen recovery, generally a grassland, shrubland or open woodland.

Trees: Brachychiton populneus, Eucalyptus melanophloia.

Tall shrubs: Geijera parviflora.

Shrubs: Mairena microphylla, Notelaea microcarpa, Carissa ovata, Nyssanthes diffusa, Solanum parvifolium, Oncinocalyx betchei, Acacia decora, Acacia deanei.

Climbers \& trailers: none apparent.

Ground cover: Austrostipa verticillata, Einadia nutans, Cyperus gracilis, Austrostipa scabra, Vittadinia dissecta, Calotis lappulacea, Bothriochloa decipiens, Urtica incisa, Malvastrum coromandelianum, Geranium solanderi, Eragrostis leptostachya, Einadia hastata, Rumex brownii, Ranunculus sessiliflorus, Oxalis perennans, Dichondra sp. A, Cymbonotus lawsonianus, Carex breviculmis, Sigesbeckia australiensis, Rorippa eustylis, Panicum simile, Chrysocephalum semipapposum, Arthropodium sp. A, Aristida personata.

Introduced taxa: Arctotheca calendula, Anagallis arvensis, Opuntia aurantiaca, Bidens pilosa, Verbena bonariensis, Conyza bonariensis, Cirsium vulgare, Urtica urens, Marrubium vulgare, Centaurea melitensis, Abutilon theophrasti.

Notes \& conservation status: again like Community 6 this assemblage may have been derived from Community 2 but most likely is derived from Community 3. This assemblage is found primarily on ridge and hillslopes and may have contained Semi-evergreen Vine Thicket that in time could return. The notes provided for Community 6 also apply here.

Community 8: Eucalyptus melliodora (Yellow Box) Eucalyptus dealbata (Tumbledown Gum) Open Woodland and Derived Grassland

Structure: variable due to past clearing practices and subsequent recovery but generally a grassland or open woodland.

Trees: Eucalyptus melliodora, Eucalyptus dealbata.

Shrubs: Notelaea microcarpa, Acacia neriifolia.

Climbers \& trailers: none apparent.

Ground cover: Austrostipa verticillata, Carex inversa, Bothriochloa decipiens, Daucus glochidiatus, Cyperus gracilis, Urtica incisa, Oxalis perennans, Geranium solanderi, Chrysocephalum semipapposum, Senecio quadridentatus, Rumex brownii, Cymbonotus lawsonianus, Carex incomitata

Introduced taxa: Verbena bonariensis, Bidens pilosa, Conyza bonariensis, Verbascum virgatum, Marrubium vulgare, Hypochaeris glabra, Stachys arvensis, Sonchus oleraceus, Solanum nigrum, Opuntia aurantiaca, Centaurea melitensis.

Notes \& conservation status: this community is largely a derived grassland probably originally a grassy woodland type with Eucalyptus melliodora (Yellow Box), Angophora floribunda (Rough-barked Apple) with at times Eucalyptus camaldulensis (River Red Gum), Eucalyptus melanophloia (Silver-leaved Ironbark) and Eucalyptus dealbata (Tumbledown Gum). This community potentially had scattered shrubs but potentially could have been termed a Box Gum Grassy Woodland The understory is largely exotic in terms of cover in some locations and with the addition of the removal of the overstorey would mean that such areas fall outside of the Threatened Ecological Community (TEC) determinations of the EPBC or TSC Acts for Grassy Box Gum Woodland Control of weeds would cause the recovered stands to fall within the TEC determinations. However there are stands that include largely native understory and also remnant trees and thus would fall within the determinations as TEC. In this broad sense this type of assemblage is common along the western side of the tablelands and along the slopes from over the Queensland border south to northern Victoria.

\section{Threatened Ecological Communities and Species}

Current methods for the circumscription of vegetation mapping units fall generally into two distinct camps; that of the mapping of pre-defined units, and the analysis and creation of specific entities based on available data. The former is not a scientific process but one that is often necessary as both landscape planning and management require a consistent set of units that can be used by all in order to enable effective cross comparison. It is important that the purposes of the investigation dictate which form of community description and mapping is the more relevant to use and even if both may be required. Within this investigation mapping polygons were assigned community names and their boundaries delineated based on explicit results from floristic analysis. Analysis of such locally collected site data reveals nuances in local species associations that are generally lost from formal descriptions of communities based on pre-determined broader geographic treatments. However there is utility in these broader formal descriptions for understanding landscape issues and for enabling others who are less familiar with the analysis methodology and results to understand contextually what the answers represent.

Pre-defined regional or statewide types are increasingly based on a broad analysis of floristic data and therefore there is an attempt to have a scientific basis underpinning the formation of these circumscribed units. This process is useful and attempts at a compromise between the two types of community delineation described above. While this is both necessary and commendable it is not a fully scientific process but only partially so. This is because the results obtained are only truly relevant, in a scientific sense, for the data available at the time, the methodology used for analysis (which may not be relevant to some projects at the scale at which the analysis was performed). Land managers necessarily need to understand that both of the methodologies outlined are not interchangeable even though there can be overlap in the general description of units and their component floras and also in the fact that each method can inform on each other. However perceived overlap in the circumscription of units should not be confused with replaceability of one form over another.

The analysis of cover/abundance scores takes into consideration all species present, the scores given to them, co-occurrence and richness. For this reason overstorey species, ones that are the most commonly seen, are only part of a defined 'community' or assemblage. Overstorey species can often be common across many floristic units. Furthermore the overstorey may change yet the understoreys can be largely similar (as with Community 2). In the former instance what may appear to be a similar community because it contains the same overstorey trees may have an entirely different understorey. It is important to recognise these differences as the understorey comprises most of the floristic diversity. To ignore most species in favour of a single life form (trees for instance) will severely underestimate the diversity in a landscape. Furthermore how management occurs within floristic units should be directed to the overall composition not only on one component (such as the overstorey). It is 
therefore highly important to recognise floristically analysed units even though reliance on overstorey dominants may be easier for non-specialist recognition. For specific purposes other forms of interpretation that rely less of floristic analysis may be useful especially when comparing data surveyed under different seasons, intensities or by a variety of methods. For example the process of relying on floristic analysis cannot be used solely to help define some highly important management units such as Threatened Ecological Communities (TECs). In general non-quantitative methods rely more arbitrary decisions and are more often than not used to assist us in delineating units that are thought to be present when statistical inference suggests otherwise.

The analysis procedure treats all species within a site as equally important. This is essential as an individual species may or may not be present at any given site due to the randomness of nature, such as opportunistic germination and establishment or localised extinction. Thus an analysis procedure may group sites even though the overstorey may contain different species as long as the majority of species and their cover within sites is largely the same. The opposite may also be true, where some generally common understorey species within a community may inexplicably be missing however the majority of other species are the same.

Unfortunately floristic analysis of locally derived data often does not correspond directly to Threatened Ecological Communities (TECs) listed on the Commonwealth Environmental Protection and Biodiversity Act and the New South Wales Threatened Species Conservation Act. In some instances a listed TEC may form part of many floristic units defined by analysis or several TECs may be defined within a single analysed floristic unit. For example derived grasslands (such as Community 7) may have originated from more than one TEC though analysis would suggest that currently they are the same unit as most of the current species are the same. As many TECs also include their derived forms it is important to map separate grassland units based the potential progenitor TEC even though at this present time there is no floristic difference. Unfortunately condition criteria are sometimes included within the delineation of TECs that cannot be incorporated in general floristic analysis, for example the method used here. As such it is nearly impossible to delineate TEC units which have condition criteria based on analysis methods. Further confusion occurs when similar TECs are listed on both the TSC and the EPBC Acts but different criteria are used to define the TEC boundaries. In addition some TECs are defined largely not on the flora contained but on their occurrence within specific environments or locations (such as certain soil types, geologies, flood levels etc). In many of these situations only a subjective approach based on the experience of the surveyor can be used in delineating mapping boundaries.

In total 66 ha of lands were found to fall within the determination of at least three TECs; Aquatic Ecological Community in the Natural Drainage System of the Lowland Catchment of the Darling River, White Box - Yellow Box Blakely's Red Gum Grassy Woodland and Derived Native Grassland and Semi-evergreen Vine Thickets of the Brigalow
Belt (North and South) and Nandewar Bioregions (Table 2). All of the Aquatic Ecological Community was considered to be in good condition, most of the Semi-evergreen vine thickets were considered to be in good to moderate condition, however almost all of the White Box - Yellow Box - Blakely's Red Gum was in poor condition.

Dodonaea stenophylla is the only species within Little Bora that is currently considered to be of listed conservation significance (NSW Threatened Species Conservation Act; profile accessed 27 Jan 2013). This species is currently listed as presumed extinct within New South Wales. However it has recently been found in large numbers within the nearby Mehi and Noonga sections of the Gwydir River Community Conservation Areas (Hunter 2010b; 2012c). While the total population within the property was not assessed it was found in a number of locations associated with Community 2 and particularly nearby and within Community 3 but not as numerous as within Mehi or Noonga.

\section{Conclusion}

Little Bora includes one species previously thought extinct, Dodonaea stenophylla; it is also recently known from the nearby Mehi and Noonga sections of the Gwydir River National Park (Hunter 2010b; 2012c). Despite past logging practices at least $65 \%$ of the property is considered to be in good condition and a further $19 \%$ in moderate condition with at least $12 \%$ likely to fall within one of three Threatened Ecological Communities; Aquatic Ecological Community of the Lower Darling, Semi-Evergreen Vine Thicket or Grassy Box Gum Woodlands. Thus Little Bora is a highly significant private reserve that if managed correctly will only increase in its importance in terms of preserving local flora and vegetation. The imposition of pre-defined floristic units over new data is not a scientific process and neither is the placing of analysed units into pre-determined types. The mapping of floristically analysed assemblages and the mapping of pre-determined types even if they have been derived from analysis (using other data) are different essentially methodologies done for different purposes, at a different time using different scales and should be kept separate. However each method has its utility particularly in terms of landscape planning and it is argued that one should never supersede the other. Within this paper both where necessary to fully inform on the management issues at hand. The mapping of floristically defined units based on the locally collected data is essential to properly understand the nuances of the local environment. These units are testable and provide a locally relevant hypothesis on of assemblages and species co-occurrence that can then be used to understand changes that may occur within them due to management change, changes in climate or the evolution of local entities. However management also needs to take into consideration the importance of some pre-defined types such as threatened communities. Thus both methods are probably essential, however they are different approximations of the world and despite overlap they are not the same and are not equivalent. Time and money constraints often mean that 
only one method can be used however it is important to be clear about when and which method is being used and what constraints this may lead to in terms of interpreting results. Despite the perceived usefulness of fitting locally defined floristic assemblages into pre-defined entities it is important that the original results of floristic analyses are kept separate and a clear distinction is maintained between the how names and types are derived.

\section{Acknowledgments}

The author would like to thank Gary Chorley \& Susanne Hiemer for allowing the opportunity to survey Little Bora and for assistance in the field.

\section{References}

Beadle, N.C.W. (1981) The Vegetation of Australia. (Cambridge University Press: Cambridge).

Belbin, L. (1995a). Users guide: PATN Pattern Analysis Package. (Division of Wildlife \& Ecology CSIRO: Canberra)

Belbin, L. (1995b). Technical Reference: PATN Pattern Analysis Package. (Division of Wildlife \& Ecology CSIRO: Canberra).

Benson, J.S., Dick, R. \& Zubovic, A. (1996) Semi-evergreen Vine Thicket vegetation at Derra Derra Ridge, Bingara, New South Wales. Cunninghamia 4: 497-510.

Curran, T.J., Clarke, P.J. \& Bruhl, J.J. (2008) A broad typology of dry rainforests on the western slopes of New South Wales. Cunninghamia 10: 381-405.

Hunter, J.T., Kingston, J. \& Croft P. (1999) Vegetation and floristics of Kwiambal National Park and surrounds, Ashford, New South Wales. Cunninghamia 6: 351-378.

Floyd, A.G. (1990) Australian rainforest in New South Wales. (Surrey Beattie and Sons: Chipping Norton).

Hunter, J.T. (2003) Vegetation of Arakoola Nature Reserve, North Western Slopes, New South Wales. Cunninghamia 8: 157-284.

Hunter, J.T. (2006) Vegetation and floristics of the Planchonella Nature Reserve. Unpublished report to the NSW Department of Environment and Climate Change.

Hunter, J.T. (2008) Vegetation and floristics of the Warrabah National Park. Unpublished report to the NSW Department of Environment and Climate Change.

Hunter, J.T. (2009a) Vegetation and floristics of the Derra Derra section of the Bingara State Conservation Area. Unpublished report to the Department of Environment and Climate Change.

Hunter, J.T. (2009b) Vegetation and floristics of the Sepoy section of the Gwydir River National Park. Unpublished report to the NSW Department of Environment, Climate Change and Water.

Hunter, J.T. (2009c) Vegetation and mapping of Bullala National Park. Unpublished report to the NSW Department of Environment, Climate Change and Water.

Hunter, J.T. (2009d) Vegetation and mapping of Terri Hie Hie Aboriginal Area. Unpublished report to the NSW Department of Environment, Climate Change and Water.

Hunter, J.T. (2009e) Vegetation and mapping of Berygill Aboriginal Area. Unpublished report to the NSW Department of Environment, Climate Change and Water.

Hunter, J.T. (2009f) Vegetation and mapping of Courallie Aboriginal Area. Unpublished report to the NSW Department of Environment, Climate Change and Water.

Hunter, J.T. (2009g) Vegetation and mapping of the Mission Aboriginal Area. Unpublished report to the NSW Department of Environment, Climate Change and Water.
Hunter, J.T. (2009h) Vegetation and mapping of Irragrippa Aboriginal Area. Unpublished report to the NSW Department of Environment, Climate Change and Water.

Hunter, J.T. (2009i) Vegetation and mapping of Campbell and Montrose Aboriginal Areas. Unpublished report to the NSW Department of Environment, Climate Change and Water.

Hunter, J.T. (2009j) Vegetation and mapping of Gunyerwarildi National Park. Unpublished report to the NSW Department of Environment, Climate Change and Water.

Hunter, J.T. (2009k) Vegetation and floristics of Horton Falls National Park. Unpublished report to the NSW Department of Environment, Climate Change and Water.

Hunter, J.T. (20091) Vegetation and floristics of the Molroy section of the Bingara State Conservation Area. Unpublished report to the NSW Department of Environment, Climate Change and Water.

Hunter, J.T. (2010a) Vegetation and floristics of Euroka. Unpublished report to the Nature Conservation Trust.

Hunter, J.T. (2010b) Vegetation of the Mehi section of the Gwydir River National Park. Unpublished report to NSW Department of Environment, Climate Change and Water.

Hunter JT (2011a) A broad brush-stroke test of an assumption: does increasing Callitris cover reduce native species richness (species density)? Cunninghamia 12, 115-118

Hunter, J.T. (2011b) Vegetation and floristics of Munro South section of the Gwydir River National Park. Unpublished report to the NSW Department of Environment, Climate Change and Water.

Hunter, J.T. (2012a) Vegetation and floristics of Warialda North and South. Unpublished report to the NSW Office of Environment and Heritage.

Hunter, J.T. (2012b) Vegetation and floristics of the Salmon and Murchison sections of the Gwydir River National Park. Unpublished report to the NSW Office of Environment and Heritage.

Hunter, J.T. (2012c) Vegetation and floristics of the Mehi Section of the Gwydir River National Park Noonga Addition Supplementary Appendix. Unpublished report to the NSW Office of Environment and Heritage.

Hunter, J.T. (2012d) Vegetation and floristics of Little Bora Nature Conservation Trust Agreement. Unpublished report to G. Chorley \& the Nature Conservation Trust.

Hunter, J.T. (2013a) Interactions between Callitris above-ground biomass, species density and plant form in north-eastern New South Wales. Australian Journal of Botany 61: 73-79.

Hunter, J.T. (2013b) Flora, Vegetation and Management Considerations: Gwydir River - Bingara. Unpublished report to the Gwydir Shire Council.

Hunter, J.T. \& Hunter, V.H. (2003) Vegetation of Ironbark Nature Reserve and the Bornhardtia Voluntary Conservation Agreement, Northern Tablelands, New South Wales. Cunninghamia 8: 93-110.

Sivertsen, D. (2009) Native Vegetation Interim Type Standard. Published by the NSW Department of Environment, Climate Change and Water.

Westhoff V, Maarel VD (1978) The Braun-Blanquet approach. In Classification of plant communities. (Ed. RH Whittaker) pp. 617-726. (Junk: The Hague, The Netherlands)

Manuscript accepted 4 December 2013 


\section{Appendix 1: Flora of Little Bora Nature Conservation Trust Agreement property.}

Taxa found within the survey sites are scored according to their occurrence in each of the eight communities defined. LB1 = Melaleuca bracteata - Eucalyptus melanophloia - Eucalyptus camaldulensis, LB2 = Callitris glaucophylla - Eucalyptus melanophloia - Eucalyptus albens, LB3 = Callitris glaucophylla - Eucalyptus melanophloia - Brachychiton populneus, LB4 = Eucalyptus albens, LB5 = Eucalyptus caleyi - Eucalyptus albens - Callitris glaucophylla, LB6 = Callitris glaucophylla Eucalyptus melanophloia - Eucalyptus albens, LB7 = Austrostipa verticillata - Austrostipa scabra, LB8 = Eucalyptus melliodora Eucalyptus dealbata. Nomenclature follows that of PlantNET. * denotes exotic species.

\section{Taxon}

Acanthaceae

Brunoniella australis Rostellularia

adscendens subsp.

adscendens

\section{Adiantaceae}

Adiantum atroviride

Cheilanthes distans

Cheilanthes sieberi

subsp. sieberi

\section{Amaranthaceae}

Nyssanthes diffusa

Amaryllidaceae

Crinum flaccidum

Anthericaceae

Arthropodium

milleflorum

Arthropodium sp. A

Laxmannia gracilis

Apiaceae

Ciclospermum

leptophyllum *

Daucus glochidiatus

Hydrocotyle laxiflora

LB1 LB2 LB3 LB4 LB5 LB6 LB7 LB8

\section{Apocynaceae}

Alstonia constricta

Carissa ovata

Parsonsia

eucalyptophylla

\section{Asclepiadaceae}

Gomphocarpus

fruticosus *

Marsdenia viridiflora

Aspleniaceae

Asplenium

flabellifolium

\section{Asteraceae}

Arctotheca calendula

Bidens pilosa *

Calotis lappulacea

Cassinia quinquefaria

Centaurea melitensis *

Chrysocephalum

apiculatum

Chrysocephalum

semipapposum
Taxon

LB1 LB2 LB3 LB4 LB5 LB6 LB7 LB8

\begin{tabular}{|c|c|c|c|c|c|c|c|}
\hline Cirsium vulgare * & 1 & 1 & & & & 1 & 1 \\
\hline Conyza bonariensis * & 1 & 1 & 1 & & & 1 & 1 \\
\hline Conyza sumatrensis * & & 1 & & & & & \\
\hline Cymbonotus & & 1 & 1 & & & 1 & 1 \\
\hline $\begin{array}{l}\text { lawsonianus } \\
\text { Euchiton } \\
\text { gymnocephalus }\end{array}$ & 1 & & & & & & \\
\hline Glossocardia bidens & & 1 & 1 & 1 & & & \\
\hline Hypochaeris glabra* & 1 & & & & & 1 & \\
\hline Hypochaeris radicata * & & 1 & & & & 1 & \\
\hline Lagenophora stipitata & & 1 & & & & 1 & \\
\hline Olearia elliptica & 1 & 1 & 1 & & 1 & & \\
\hline Olearia gravis & & 1 & & & & & \\
\hline Senecio prenanthoides & & 1 & 1 & & 1 & & \\
\hline Senecio quadridentatus & & 1 & & & & 1 & \\
\hline $\begin{array}{l}\text { Sigesbeckia } \\
\text { australiensis }\end{array}$ & & 1 & 1 & & & & 1 \\
\hline Sonchus oleraceus * & 1 & 1 & & & & 1 & \\
\hline Taraxacum officinale * & & & & & & 1 & \\
\hline
\end{tabular}

Vernonia cinerea 1

var. cinerea

Vittadinia cuneata

var. cuneata

Vittadinia cuneata

var. hirsuta

Vittadinia dissecta

var. hirta

Vittadinia muelleri

Vittadinia sulcata

Bignoniaceae

Pandorea pandorana $\quad 1 \quad 1$

Brassicaceae

Rorippa eustylis

Rorippa laciniata

Cactaceae

Opuntia aurantiaca *

Opuntia stricta

var. stricta *

Campanulaceae

Wahlenbergia

communis

Capparaceae

Capparis mitchellii

Caryophyllaceae

Paronychia brasiliana *1

Scleranthus biflorus 1

Stellaria angustifolia

Stellaria flaccida

Stellaria media *

Celastraceae

Cassine australis

var. angustifolia

Chenopodiaceae

Einadia hastata

Einadia nutans

subsp. nutans

Enchylaena tomentosa

Maireana microphylla

Chloanthaceae

Spartothamnella juncea $1 \quad 1 \quad 1 \quad 1$

Clusiaceae

Hypericum gramineum 1 
Taxon

LB1 LB2 LB3 LB4 LB5 LB6 LB7 LB8 Taxon
LB1 LB2 LB3 LB4 LB5 LB6 LB7 LB8

\section{Colchicaceae}

Wurmbea dioica subsp. $\quad 1 \quad 1$

dioica

Convolvulaceae

Dichondra repens

Dichondra sp. A

Crassulaceae

Crassula sieberiana

Cupressaceae

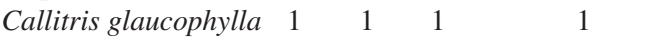

\section{Cyperaceae}

Carex breviculmis

Carex incomitata

Carex inversa

Cyperus eragrostis

Cyperus fulvus

Cyperus gracilis

Lepidosperma laterale 1

Scleria mackaviensis

Dennstaedtiaceae 1

Calochlaena dubia 1

Dilleniaceae

$\begin{array}{llllll}\text { Hibbertia obtusifolia } & 1 & 1 & 1 & 1 & 1\end{array}$

Hibbertia riparia

Epacridaceae

Melichrus urceolatus

Euphorbiaceae

Beyeria viscosa

Breynia cernua

Chamaesyce

drummondii

Phyllanthus

subcrenulatus

Poranthera microphylla

Fabaceae

Acacia cheelii

Acacia deanei subsp.

deanei

Acacia decora

Acacia implexa

Acacia leiocalyx subsp. 1

leiocalyx

Acacia neriifolia

Desmodium

brachypodum

Desmodium varians

Glycine clandestina

Glycine microphylla

Glycine tabacina

Hovea lanceolata

Isotropis foliosa

Lotus cruentus

Medicago

polymorpha*

Swainsona galegifolia

Trifolium dubium *

Trifolium repens $*$

Fumariaceae

Fumaria capreolata

subsp. capreolata *

\section{Gentianaceae}

Centaurium

tenuiflorum *
Geraniaceae

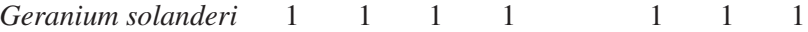
var. solanderi

Goodeniaceae

Brunonia australis

Haloragaceae

Gonocarpus elatus

1

Gonocarpus micranthus 1

subsp. micranthus

Haloragis heterophylla $1 \quad 1$

Haloragis serra

Juncaceae

Juncus aridicola

Juncus remotiflorus

Lamiaceae

Ajuga australis

Marrubium vulgare *

Stachys arvensis * 1

Lobeliaceae

Isotoma axillaris

Pratia purpurascens 1

Lomandraceae

Lomandra filiformis

Lomandra longifolia

Lomandra multiflora

subsp. multiflora

Loranthaceae

Amyema pendulum

subsp. longifolium

Amyema pendulum

subsp. pendulum

Luzuriagaceae

Eustrephus latifolius

Malvaceae

Abutilon oxycarpum 11

Abutilon theophrasti

Abutilon tubulosum

Hibiscus sturtii var.

sturtii

Malvastrum

coromandelianum

Sida corrugata

Moraceae

Ficus rubiginosa

Myrtaceae

Angophora floribunda $1 \quad 1$

Eucalyptus albens

Eucalyptus caleyi

subsp. caleyi

Eucalyptus

camaldulensis

Eucalyptus crebra

Eucalyptus dealbata

Eucalyptus

melanophloia

Eucalyptus melliodora

Eucalyptus moluccana

Eucalyptus sideroxylon

Melaleuca bracteata 1

Nyctaginaceae

Boerhavia dominii
1 
Taxon

LB1 LB2 LB3 LB4 LB5 LB6 LB7 LB8 Taxon

Oleaceae

Jasminum lineare

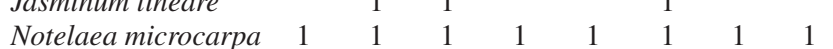

var. microcarpa

Orchidaceae

Cymbidium

canaliculatum

\section{Oxalidaceae}

Oxalis chnoodes

Oxalis perennans

Phormiaceae

Dianella revoluta var.

revoluta

\section{Pittosporaceae}

Bursaria spinosa

Plantaginaceae

Plantago debilis

Plantago lanceolata *

Plantago varia

\section{Poaceae}

Aristida calycina var.

praealta

Aristida jerichoensis

var. subspinulifera

Aristida jerichoensis

var. jerichoensis

Aristida personata

Aristida vagans

Austrodanthonia

racemosa var. obtusata

Austrodanthonia

racemosa var.

racemosa

Austrostipa scabra 1

subsp. scabra

Austrostipa verticillata 1

Bothriochloa decipiens 1

Bothriochloa macra

Chloris truncata

Cymbopogon refractus

Cynodon dactylon

Dichanthium sericeum

subsp. sericeum

Dichelachne micrantha

Echinopogon

caespitosus var.

caespitosus

Enneapogon nigricans

Eragrostis leptostachya

Eragrostis molybdea

Eragrostis parviflora

Hyparrhenia hirta *

Microlaena stipoides

var. stipoides

Oplismenus aemulus 1

Panicum simile

Paspalidium

constrictum

Poa sieberiana

Rytidosperma

longifolium

Sporobolus creber

Tripogon loliiformis

Polygonaceae

Rumex brownii

Primulaceae

Anagallis arvensis *
Ranunculaceae

Clematis microphylla

var. microphylla

Ranunculus

sessiliflorus var.

sessiliflorus

\section{Rhamnaceae}

Alphitonia excelsa

LB1 LB2 LB3 LB4 LB5 LB6 LB7 LB8

Cryptandra amara var.

floribunda

Rosaceae

Acaena novae-

zelandiae

Rubiaceae

Galium gaudichaudii 1

Galium migrans

Pomax umbellata

Psydrax odoratum

Rutaceae

Geijera parviflora

Santalaceae

Santalum acuminatum

Sapindaceae

Alectryon subdentatus 111

forma subdentatus

Dodonaea sinuolata

subsp. sinuolata

Dodonaea stenophylla

Dodonaea viscosa

subsp. angustifolia

Scrophulariaceae

Verbascum thapsus

subsp. thapsus *

Verbascum virgatum *

Veronica calycina

Sinopteridaceae

$\begin{array}{lll}\text { Pellaea calidirupium } & 1 & 1\end{array}$

Solanaceae

Solanum nigrum *

Solanum parvifolium

Stackhousiaceae

Stackhousia monogyna

Stackhousia viminea

\section{Sterculiaceae}

Brachychiton populneus

subsp. populneus

Thymelaeaceae

Pimelea curviflora

subsp. divergens

Pimelea micrantha

Pimelea neo-anglica

Urticaceae

Parietaria debilis

Urtica incisa

Urtica urens *

Verbenaceae

Oncinocalyx betchei

Verbena bonariensis *

Xanthorrhoeaceae

Xanthorrhoea johnsonii 1

Zamiaceae

Macrozamia diplomera 1
1 